\title{
Por uma Ordo Amoris (theologia amoris) pela promoção de uma Cultura da Paz
}

\author{
For an Ordo Amoris (amoris theology) \\ for the construction of the Culture of Peace
}

Rodrigo Cardoso Condeixa da Costa

Ama e faze o que quiseres

Santo Agostinho

Amor é coisa que mais quero

Adélia Prado

\section{Resumo}

Nossa intenção nessa comunicação é apresentar uma pequena reflexão acerca da ordo amoris, e uma teologia consequente: pautada na experiência do amor concreto que nasce de um coração humilde e aberto a Deus, ao outro, sobretudo os mais sofridos, um coração sensível ao mundo.

Palavras-chave: Ordo amoris. Theologia amoris. Coração. Cultura da paz.

\section{Abstract}

Our intention in this communication is to present a short reflection on the ordo amoris, and a consequent theology: guided by the experience of concrete love that springs from a humble heart and open to God, to each other, especially the most painful, a sensitive heart to the world.

Keywords: Ordo amoris. Amoris theology. Heart. Culture of peace. 


\section{Introdução}

O amor, na ótica cristã, constitui o chão e a baliza para a caminhada na vida concreta: no seguimento de Jesus Cristo (já que o caminho se faz caminhando $\left.{ }^{1}\right) .{ }^{2}$ É ele, o amor, a $e x$-peri-ência que dá sentido a $e x$-istência ${ }^{3}$. Afirmações como estas conquistam um inaudito significado, sobretudo, quando nos detemos na proposta (projeto de vida) do Reino de Deus segundo Jesus de Nazaré, resposta aos anseios imemoriais do "ser humano", tendo em vista uma questão crucial: o sentido da vida. Ou seja, o Reino de Deus é ao mesmo tempo uma resposta e uma proposta (da parte de Deus) aos homens e mulheres concretos, amados incondicionalmente pelo Deus-Amor, conforme a revelação bíblico-cristã. ${ }^{4}$

\section{Fora do amor não há salvação}

A partir da revelação de Deus em e mediante Jesus Cristo, a fé cristã proclama sem reservas a Alvissareira Notícia: "Deus é amor!" $\mathrm{Na}$ perspectiva evangélica, quem ama conhece a Deus e por Ele é conhecido. $^{6}$ Donde emerge a necessidade de (re)pensar o papel mistagógico ${ }^{7}$

\footnotetext{
${ }^{1}$ Pois "o real não está na saída nem na chegada: ele se dispõe para a gente é no meio da travessia”. ROSA, J. G. Grande Sertão: veredas. Rio de Janeiro: Nova Aguilar, 1994, p. 86.

${ }^{2}$ Conforme afirma o núcleo fundamental da revelação bíblico-cristã: Deus se revelou por amor. E a vida só faz sentido se vivida no amor: Cf. Mc 12, 28-34; Lc 10, 25-28; Mt 22, 36-40; Mt 25, 31-46; 1 Co 13; Gl 5, 14, entre outros.

${ }^{3}$ Pois: "Ex é uma preposição latina que significa, entre outros conteúdos, 'estar orientado para fora', 'exposto a', 'aberto para'. (...) Neste sentido, ex ex-prime uma característica fundamental do ser humano como ex-sistência. Ele é ser que ex-iste voltado para fora (ex), em diálogo e em comunhão com o outro e com o mundo. Daí ser a ex-peri-ência não apenas uma ciência, mas uma verdadeira cons-ciência." BOFF, L. Experimentar Deus: a transparência de todas as coisas. Petrópolis: Vozes, 2011, p. 33.
}

${ }^{4}$ Cf. Jo 3, 16.

${ }^{5} \mathrm{Cf} .1$ Jo 4,8 .

${ }^{6}$ Cf. MOLTMANN, J. Experiências de reflexão teológica: caminhos e formas da teologia cristã. São Leopoldo: Editora UNISINOS, 2004, pp. 130-156. Neste sentido, a fé e a teologia precisam aterrissar, revestir-se de carne, como fez o Filho de Deus. A teologia não pode permanecer (tão somente) nas prateleiras, mas auxiliar no processo de discernimento da ex-peri-ência de fé, como uma mediadora. Sobre o significado de ex-peri-ência. Cf. BOFF, L. Experimentar Deus. Op. cit., pp. 31-32.

${ }^{7}$ Uma teologia como mistagogia, pois: "O saber da fé é saber iniciático: vem de uma experiência comunicada por via simbólico-sacramental. É saber de convivência e comunhão. É um 
e a dimensão étic $a^{8}$ da teologia relacionada a um projeto de vida pautado no único dogma insofismável da fé cristã: o amor. ${ }^{9}$ Sem o exercício do amorserviço, a vida e o conhecimento de Deus ficam irremediavelmente comprometidos. ${ }^{10}$ Há aqui, portanto, uma profunda retro-inter-relação entre mística e ética. Mística que significa a experiência intensa do Mistério, e nos reposiciona na trama da vida. Daí o recente caminho da teologia ocidental da volta às fontes ${ }^{11}$ : beber ininterruptamente do Espírito, portanto da espiritualidade, da mística. Bem dizia K. Rahner: "o cristão do futuro, ou será um místico ou não será cristão"12. Por isso a necessidade de uma relação umbilical entre teologia e espiritualidade, que se dá no Espírito, por meio do corpo. ${ }^{13} \mathrm{Um}$ projeto de vida pautado no amor: no compromisso com a justiça, na afirmação da vida, na contramão da cultura de morte - fruto da experiência do Espírito como Mãe da vida ${ }^{14}$, que nos interpela ao descentramento, a uma dinâmica de alteridade ${ }^{15}$.

O labor teológico, nesta perspectiva, se dá (sempre) desde dentro desta

saber 'desde dentro', não 'desde fora'. Daí porque o mero 'cientista da religião' jamais saberá como sabe o crente e o teólogo crente. Não saberá avaliar corretamente a substância da fé em questão (...). Daí a afirmação de Santo Anselmo: Quem não crer, não experimentará; e quem não tiver experimentado, não entenderá”. BOFF, C. Teoria de método teológico. $5^{\mathrm{a}}$ ed. Petrópolis: Vozes, 2004, p. 130. Grifo nosso.

${ }^{8}$ De ethos, morada na qual habitamos. Cf. BOFF, L. Ética e ecoespiritualidade. Petrópolis: Vozes, 2011, pp. 9-12.

${ }^{9}$ Cf. Jo 13, 34. Cf. também. VATTIMO, G.; RORTY, R. O futuro da religião. Solidariedade, caridade e ironia. Rio de Janeiro: Relume Dumará, 2006, p. 71. O seguimento de Jesus coloca no centro este princípio ético fundamental: o amor.

${ }^{10}$ Jon Sobrino diz que só mediante o seguimento de Jesus Cristo é possível verdadeiramente conhecê-lo e, assim, conhecer a Deus. Cf. SOBRINO, J. A fé em Jesus Cristo: ensaio a partir das vítimas. Petrópolis: Vozes, 2000, pp. 462-487.

${ }^{11}$ LIBÂNIO, J. B. \& MURAD, A. Introdução à teologia: perfil, enfoques e tarefas. São Paulo: Loyola, 1996, pp. 145-147.

${ }^{12}$ RAHNER, K. O cristão do futuro. São Paulo: Novo Século, 2004, p. 78.

${ }^{13}$ Cf. CONDEIXA, R. Do divórcio ao romance: uma nova relação entre teologia e espiritualidade. São Paulo: Editora Reflexão, 2011.

${ }^{14}$ Cf. MOLTMANN, J. A Fonte da Vida: o Espírito Santo e a teologia da vida. São Paulo: Loyola, 2002. Cf. também. Id. O Espírito da Vida: uma pneumatologia integral. Petrópolis: Vozes, 1999, pp. 29-155; Id. Trindade e Reino de Deus: uma contribuição para a teologia. Petrópolis: Vozes, 2000, pp. 18-24.

${ }^{15}$ Outro que é alguém concreto, que me interpela, a quem sou con-vocado a responder. O tema da alteridade tem sido amplamente desenvolvido na reflexão filosófica contemporânea. Cf. LÉVINAS, E. Totalidade e Infinito. Lisboa: Edições 70, 2008; Id. Entre nós: ensaios sobre a alteridade. Petrópolis: Vozes, 2005. 
dinâmica, ${ }^{16}$ isto é, a partir desta experiência fulcral: a experiência do amor ${ }^{17}$. Esta ex-peri-ência tem como modelo a Comunidade de Amor (Pai, Filho, e Espírito Santo) ${ }^{18}$, pois Deus é Relação. ${ }^{19}$ Diz Maria Clara L. Bingemer:

A revelação cristã é vista como a história das relações trinitárias de amor, abertas ao ser humano e ao mundo. A teologia trinitária é pensada em termos de comunidade e alteridade, e a experiência é considerada lugar epistemológico (...) central da reflexão. O gênero literário empregado é o narrativo, importa não tanto deduzir e especular sobre Deus, sua pessoa e seus atributos, mas narrar a história da relação amorosa de Deus com a humanidade. E o objeto da narrativa é o mistério de um Deus que se revela como mysterium salutis (mistério de salvação) e não como mysterium logicum (mistério lógico). A pergunta fundamental, portanto, deixa de se concentrar no "Deus existe? Pode-se provar a sua existência?", e volta-se para "O que significa para nós, hoje, a existência de Deus? De que Deus se trata? De que Deus somos crentes e de que Deus somos ateus?". ${ }^{20}$

Somos crentes do Deus-Amor, por isso: "Fora do amor não há salvação!". No entanto, por mais verdadeiramente cristã que seja esta afirmação e princípio fundamental, esta não pode restringir-se (reduzir-se) à salvação em sentido escatológico individual. Não. Pois, na realidade, sem amor não há viabilidade para a vida! E se a vida como um todo não é viável sem amor, por que motivo a teologia não estaria incluída? Ou seja, não é possível uma teologia autenticamente cristã (que se sustente) estando ausente esta experiência vital:

\footnotetext{
${ }^{16}$ Uma teologia pneumática e uma sapientia fidei. Cf. GUTIÉRREZ, G. Beber no próprio poço: itinerário de um povo. São Paulo: Loyola, 2000, pp. 69-70; BARTH, K. Introdução à teologia evangélica. $9^{a}$ ed. São Leopoldo: Sinodal, 2007, pp. 35-40.

${ }^{17}$ Cf. BARTH, K. Introdução à teologia evangélica. Op. cit., pp. 123-128. Cf. também. BINGEMER, M. C. L.; FELLER, V. G. Deus-Amor: a graça que habita em nós. São Paulo: Paulinas; Valência: Siquem, 2003, p. 9.

${ }^{18}$ Cf. BINGEMER, M. C. L.; FELLER, V. G. Deus Trindade: a vida no coração do mundo. São Paulo: Paulinas; Valência: Siquem, 2003, p. 10.

${ }^{19}$ A unidade em Deus é fruto da relação, como um "laço indissolúvel" entre as Três Divinas Pessoas: a relação faz o laço, o laço é a própria relação. A relação acontece, ou melhor, "é" a própria "essência" de Deus. Ou seja, a unidade não é o "resultado" a posteriori ou sustentada ( $a$ priori) numa consubstancialidade metafísico-essencialista, mas dá-se na e pela interpresença, interpenetração, inter-retro-relação (pericóresis). A unidade é a própria relação: a relação é o laço (ou faz o Laço). Cf. especialmente. MOLTMANN, J. Trindade e Reino de Deus: uma contribuição para a teologia. Petrópolis: Vozes, 2000, pp. 24-33.
}

${ }^{20}$ BINGEMER, M. C. L.; FELLER, V. G. Deus Trindade. Op. cit., p. 27. Grifo nosso. 
Por isso, o amor foi também sempre para nós, ao mesmo tempo, o acto primigénio, pelo qual um ente - sem deixar de ser este ente limitado se abandona a si mesmo para, enquanto ens intentionale, participar e ter parte noutro ente, mas de modo que eles não se tornem quaisquer partes reais um do outro. Por isso, o que chamamos "conhecer" - esta relação de ser - pressupõe sempre este acto originário: um abandonar-se a si e aos seus estados, os seus peculiares "conteúdos de consciência", ou um transcendê-los para, segundo a possibilidade, chegar a um contacto vivencial com o mundo. ${ }^{21}$

Ou seja, sem a experiência/vivência concreta do Amor, que se expressa (também) como amor mundi $i^{22}$, o próprio labor teológico fica impossibilitado. ${ }^{23}$ Motivo primordial da premente necessidade, na teologia, de uma razão cordial-amorosa (odre du coeur). É a ordem do coração, do qual falava Blaise Pascal. Para o pensador de Port-Royal, somente por meio da conversão do coração (verdadeira conversão) no qual atua a caritas, que homens e mulheres conhecem a Deus, e por meio dele (do coração) podem agir em consonância ao Amor experienciado. Para B. Pascal, é somente por meio do Espírito, que penetra as profundezas do humano, que podemos experienciar o profundo da vida, que se traduz na transfiguração da vida pela vivência concreta do Amor. Essa experiência vitalista não é passível de dar-se senão pelo Amor. O conhecimento meramente racional de Deus (no sentido empregado por B. Pascal) e, por conseguinte, do outro, do próximo, sequer "arranha" as estranhas humanas. É mister o affectus, o pathos, que dinamiza e envolve a pessoa por inteiro. Conforme diz B. Pascal no fragmento L. 423; Br. 277:

O coração tem razões que a razão desconhece, sabe-se disso em mil coisas. Digo que o coração ama o ser universal e a si mesmo, conforme ao que se dedica, e ele se endurece contra um ou outro à sua escolha. Rejeitastes a um e ficastes com o outro; será pela razão que vos amais? $?^{24}$

\footnotetext{
${ }^{21}$ SCHELER, M. "Ordo amoris”. Tradutor: Artur Mourão. In: LusoSofia. Biblioteca on-line de Filosofia e Cultura, p. 14. Disponível em: <http://www.lusosofia.net/textos/20120726-scheler ordo_amoris.pdf $>$. Acessado em 8 de julho de 2015.

${ }^{22}$ Cf. MAFFESOLI, M. Homo eroticus: convivências emocionais. Rio de Janeiro: Forense Universitária, 2014, p. 10.

${ }^{23}$ Pois, "fora do mundo não há salvação": Cf. SCHILLEBEECKX, E. História humana: revelação de Deus. $2^{\mathrm{a}}$ ed. São Paulo: Paulus, 2003, pp. 21-33.

${ }^{24}$ PASCAL, B. Pensamentos. $2^{\text {a }}$ ed. São Paulo: Martins Fontes, 2005, p. 164.
} 
O amor, aprendemos com B. Pascal, não é o resultado de profundas ponderações lógicas, racionais, acerca de alguém, incluindo Deus, mas nasce misteriosamente das entranhas do humano, isto é, do coração. Daí a centralidade do coração, ou seja, fora do coração não há salvação!

\section{Fora de um coração aberto e humilde ${ }^{25}$ não há salvação}

Estes são princípios de afirmação da vida: fermento para as relações humanas, para a vida em comunidade, em sociedade. ${ }^{26}$ Do contrário, há o risco da barbárie, a prevalência da cultura de morte, da violência desmedida, da intolerância radical, fruto da hybris desenfreada, próprio da estupidez humana. ${ }^{27}$

Todavia, é na esfera das pequenas relações, no interior do cotidiano mais comezinho que o amor precisa ser encarnado: como uma nova forma de vínculo comunitário, social, que vá para além do contrato social, conforme preconiza certo pensamento político herdado do Iluminismo. ${ }^{28}$ Um pensamento que não rompe com a lógica do individualismo. Muito pelo contrário. Daí a premente necessidade de outra lógica, outro modo de ver e viver a vida, agora não mais fundamentada no $\mathrm{Eu}$ com referência primordial (portanto, numa egologia qualquer), mas num "nós": uma relação-união que acontece a partir do afeto,

\footnotetext{
${ }^{25}$ Tecer uma práxis de vida e uma teologia a partir de uma singular imagem de Deus, do Deus Comunidade de Amor: Pai, Filho, e Espírito Santo, em permanente dinâmica de kénosis. Uma dinâmica de vida e teológica inspiradas na vida do Pai, do Filho, e do Espírito Santo: na dinâmica da kénosis Trinitária. Cf. FORTE, B. Teologia em diálogo: para quem quer e para quem não quer saber nada disso. São Paulo: Loyola, 2002, pp. 76-77; BOFF, L. A Santíssima Trindade é a melhor comunidade. $11^{\mathrm{a}}$ ed. Petrópolis: Vozes, 2009, pp. 30-35; SUSIN. L. C. "Gloria Maior Deus Humilis". Prática da Teologia em novos paradigmas: um exercício. In: VV. AA. Teologia aberta ao futuro. São Paulo: SOTER; Loyola, 1997, pp. 124-125.

${ }^{26}$ Um Deus que é pura Doação. A dinâmica kenótico-trinitária revela-se como: a kénosis do Pai - como contração de potência; a kénosis do Filho - como renuncia à majestade; e a kénosis do Espírito - como humildade e descrição. Cf. ROCHA, A. Espírito Santo: aspectos de uma pneumatologia solidária à condição humana. São Paulo: Vida, 2008, pp. 90-101.

${ }^{27}$ Cf. MORIN, E. Amor, poesia, sabedoria. $7^{\mathrm{a}}$ ed. Rio de Janeiro: Bertrand Brasil, 2007, pp. 7-8. Estupidez comum ao homo demens-demens. Cf. MORIN, E. O Método 5: a humanidade da humanidade. $5^{\text {a }}$ ed. Porto Alegre: Sulina, 2012, pp. 115-128. Pois, "temos a dimensão sã e também a patológica. Porque não somos só homo sapiens-sapiens. Somos hoje, fundamentalmente, homo demens, duplamente demens, coisa esquecida na modernidade iluminista". BOFF, L. Tempo de transcendência: o ser humano como um projeto infinito. Rio de Janeiro: Sextante, 2000, p. 27.

${ }^{28}$ Cf. ROUSSEAU, J. J. Do contrato social. (Col. Saraiva de Bolso). São Paulo: Saraiva; Nova Fronteira, 2011.
} 
que fomenta e sedimenta o estar- $\operatorname{com}^{29}$, que potencializa nosso ser-no-mundocom e para-os-outros, como cuidado, fenômeno que se dá primordialmente a partir do coração. ${ }^{30}$

Para os antigos, sobretudo para os gregos, o amor era percebido como uma energia humana fundamental, presente nas relações, sobretudo no que dizia respeito à ação do homem na polis: daí Eros predominar na concepção grega de amor. Na obra $O$ Banquete, texto clássico no qual Platão busca formular sua compreensão de amor, Eros é tratado como uma força misteriosa: visto ora como um deus, ora como um dáimon, um demiurgo. ${ }^{31}$ Uma pulsão vital, como dirá mais tarde a psicanálise freudiana que tanto recorreu à cultura grega (mitologia/filosofia) para construir seu arcabouço conceitual. ${ }^{32}$ Mas, sem prescindir da dimensão "erótica do humano" ${ }^{33}$, precisamos dar um passo a mais quando pensamos a possibilidade da criação de uma ordo amoris: formada a partir de uma sensibilidade sui generis: no exercício de uma amorosidade ilimitada, e uma ecosofia sensivel ${ }^{34}$. Entretanto, esta outra ordem de coisas só pode acontecer a partir do coração, do corpo como grande órgão de percepção e doação de sentido. Tal como diz o poeta russo:

Nos demais - eu sei, qualquer um o sabe -

O coração tem domicílio no peito.

Comigo a anatomia ficou louca.

Sou todo coração - em todas as partes palpita. ${ }^{35}$

Maiakovski faz ressoar a cara herança de um tema bíblico: do coração como o centro da vida (do dinamismo interior da pessoa); do "coração de carne" dado pelo Espírito em detrimento do "coração de pedra" ${ }^{36}$. Segundo

\footnotetext{
${ }^{29}$ Cf. MAFFESOLI, M. Homo eroticus. Op. cit., pp. 81-103.

${ }^{30}$ Cf. BOFF, L. O cuidado necessário. Petrópolis: Vozes, 2012, pp. 44-65.

${ }^{31}$ Cf. PLATÃO. O Banquete ou do Amor. Rio de Janeiro: DIFEL, 2002.

${ }^{32}$ É a relação entre pulsão de vida e pulsão de morte, entre Eros e Thanatos: diferencial da "última fase" do pensamento freudiano. Cf. FREUD, S. O mal-estar na civilização. São Paulo: Penguin Classics; Companhia das Letras, 2011, pp. 64-66.

${ }^{33}$ Sobretudo a partir do resgate da corporeidade no pensamento contemporâneo: Cf. BATAILLE, G. O erotismo. Porto Alegre: L\&PM, 1987; PAZ, O. A dupla chama: amor e erotismo. $2^{\mathrm{a}}$ ed. São Paulo: Siciliano, 1995.

${ }^{34}$ Cf. MAFFESOLI, M. Homo eroticus. Op. cit., pp. 235-261.

${ }^{35}$ MAIAKÓVSKI, V. Antologia poética. 4a ed. São Paulo: Max Limonad, 1987, p. 143.

${ }^{36} \mathrm{Cf}$. Ez 36, 26.
} 
a tradição bíblica, o coração do homem e da mulher pode ser orgulhoso e vão, resistindo a Deus, e aos irmãos e irmãs, mas pode igualmente converterse: tornar-se dócil à ternura de Deus, gestando um novo modus vivendi: da ternura, do cuidado, da gentileza. ${ }^{37}$ Ora, segundo a revelação (de Deus em Cristo no Espírito $^{38}$ ), o amor de Deus é de outra ordem: revela-se em sua absoluta gratuidade e soberana iniciativa (unilateral). Ou seja, o Amor não pode ser conquistado e/ou merecido pelo "ser humano", mas pode e carece ser acolhido no coração ${ }^{39}$ como Dom (Ágape). Pois o próprio Deus é o Dom maior, por isso seu nome também é Amor: Deus-Amor. Amor que foi plenamente acolhido, de modo único e inaudito, na carne quente de Jesus Cristo (relação divino-humana). Amor mais forte que a morte ${ }^{40}$ : que se traduz na práxis da caritas $^{41}$ - quem se doa conhece a Deus. ${ }^{42}$ Diz o teólogo mártir:

Amor significa sofrer a metamorfose de toda a existência por parte de Deus, ser incorporado ao mundo tal como ele somente pode subsistir diante de Deus e em Deus. (...) O amor de Deus não é apenas aquele porto de refúgio onde posso me abrigar do mar grosso. Ser amado por Deus de modo algum proíbe ao ser humano pensamentos fortes e ações alentadas. Somos amados e reconciliados por Deus em Cristo como seres humanos inteiros. É como seres humanos inteiros, raciocinando e agindo, que amamos a Deus e aos irmãos. ${ }^{43}$

Por isso, para que faça algum sentido (minimamente) a palavra amor (para que esta não se torne uma palavra vazia de sentido, palavra tão desgastada nos nossos dias), nada melhor que a revelação do Amor em Jesus Cristo.

\footnotetext{
${ }^{37}$ Pois como diz o profeta do Cajú: "gentileza gera gentileza". Sobre a vida e obra de José Datrino, o Profeta Gentileza: Cf. GUELMAN, L C. Univvverrsso Gentileza. Curitiba: Mundo das Idéias, 2015. Sobre a ternura: Cf. ALVES, R. Retratos de Amor. $7^{\mathrm{a}}$ ed. Campinas: Papirus, 2002, pp. 68-70. Sobre o cuidado: Cf. BOFF, L. Saber cuidar: ética do humano, compaixão pela terra. $18^{\mathrm{a}}$ ed. Petrópolis: Vozes, 2012.

${ }^{38} \mathrm{Cf}$. Rm 5, 5.

${ }^{39}$ Pela fé, que dinamiza todo o ser da pessoa: ato no qual a pessoa inteira está radicalmente envolvida. Cf. LIBÂNIO, J. B. Eu creio, nós cremos: tratado da fé. São Paulo: Loyola, 2000, pp. 9-18.

${ }^{40}$ Cf. Ct $8,6$.

${ }^{41}$ A caridade é o amor que move a vontade à busca efetiva do bem de outrem. Diz o Doutor da graça: "Meu peso é o amor; por ele sou levado para onde sou levado". AGOSTINHO, S. Confissões. São Paulo: Paulus, 2006, pp. 9-10.

${ }^{42}$ Cf. 1 Jo $4,7$.

${ }^{43}$ BONHOEFFER, D. Ética. Op. cit., pp. 34-35. Grifo nosso.
} 
Amor disponível a todos e todas: orientados existencialmente para o Reino de Deus ${ }^{44}$, por meio do Espírito que in-habita a Criação. Daí a necessidade da experiência/vivência do Deus-Amor no seguimento de Jesus Cristo, sobretudo em relação aos mais fragilizados, os pobres, ao lado dos quais o Deus da revelação se coloca ${ }^{45}$, e nos interpela para que façamos o mesmo (miseri-córdia ${ }^{46}$ ), e que toca numa questão capital: a imagem de Deus veiculada. ${ }^{47}$ Esta é uma questão nevrálgica.

Quando dizemos imagem de Deus, falamos (também) de uma dimensão estética: uma forma singular de perceber e fruir a beleza de Deus (presente no mundo, incluindo o "ser humano"): do Deus Comunidade de Amor. Donde a carência de (re)colocar a figura feminina/materna do divino, possibilitando um diálogo entre o feminino e o masculino, evitando extremismos radicais. A teologia, portanto, precisa pensar a imagem de um Deus Pai que é também Mãe ${ }^{48}$, pois: "Só na combinação de ambos aparece a vida em sua harmonia. Não porque se dissolveram as tensões, senão porque se conseguiu uma síntese cheia de tensões, que se sustenta, se renova e se aprofunda cada vez mais"49. Esta é uma imagem de Deus (tão bela) que é capaz de seduzir "pedras, catedrais, coração", como diz o poeta-cantor ${ }^{50}$. Um Deus que é pura doação de $\mathrm{Si}$, puro desbordamento de Amor. Felizmente amor e beleza andam de mãos dadas em Deus - e assim deveria ser conosco. Ao criar em amor, em graça, em, por meio de e para Cristo, na força do Espírito, o resultado só poderia ser esse: beleza e bondade. ${ }^{51}$ Que transforma o deserto árido da existência num jardim

${ }^{44}$ Cf. FRANÇA MIRANDA, M. de. A salvação de Jesus Cristo: a doutrina da graça. São Paulo: Loyola, 2003, pp. 47-48. Sobre o amor/graça como um existencial-sobrenatural: Cf. RAHNER, K. Curso fundamental da fé. $3^{\mathrm{a}}$ ed. São Paulo: Paulus, 2004, pp. 157-165.

${ }^{45}$ Como Go'el os defende. Cf. GUTIÉRREZ, G. O Deus da vida. São Paulo. Loyola, 1992, pp. 45-57.

${ }^{46}$ Cf. SOBRINO, J. Espiritualidade da libertação. São Paulo: Loyola, 1992, pp. 185-198.

${ }^{47} 1$ Jo 3, 16. Grifo nosso.

${ }^{48}$ Cf. BOFF, L. O rosto materno de Deus: ensaio interdisciplinar sobre o feminino e suas formas religiosas. Petrópolis: Vozes, 1986.

${ }^{49}$ BOFF, L. "Masculino e Feminino, o que é? Fragmentos de uma ontologia". Revista de Cultura Vozes 9 (1974), p. 684.

${ }^{50}$ DJAVAN. "Seduzir". Faixa 2. In: Seduzir. EMI/Odeon, 1981. Um Deus desarmado, que nos convida a não-violência, portanto ao diálogo, fomentando uma cultura de tolerância no caminho da fraternidade. Cf. BINGEMER, M. C. L. Um rosto para Deus? São Paulo: Paulus, 2005, pp. 159-222. ${ }^{51} \mathrm{Na}$ plenitude-recapitulação: Cf. o hino cristológico de Cl 1, 15-20; e Ef 1, 7-12. Cf. RUBIO, A. G. O encontro com Jesus Cristo Vivo: ensaio de cristologia para os nossos dias. $15^{\text {a }}$ ed. São Paulo: Paulinas, 2012, pp. 103-118/146-149. Paulo faz uma (re)leitura catacrônica da história: 
de delícias para todos e todas: cheio de beleza ${ }^{52}$, de alegria $^{53}$, de prazer $^{54}$, e de bondade ${ }^{55}$.

Ora, é exatamente por isso que os mitos permanecem vivos - como aquele do Paraíso genesíaco, com toda a sua carga simbólica e existencial. ${ }^{56}$ Já que a narrativa poética bíblica não traduz um fato, fixado no passado, mas projeta no passado (protologicamente) a derradeira esperança escatológica (plenitude escatológica), e nos fala de uma experiência presente (existencial). O Jardim é dom, mas é também tarefa (cuidar do Jardim para que floresça) e destino (o Jardim definitivo). ${ }^{57}$ O Paraíso de Gênesis é, portanto, o Paraíso esperado: da plenitude anunciada para os tempos messiânicos (Primeiro Testamento) e, pelos olhos da fé, "já" realizada em Cristo: prenuncio da recapitulação de toda a Criação. ${ }^{58}$ Não é uma questão de otimismo, mas de Esperança, pois o Deus Trindade continua criando e recriando, gerando e regenerando todas as coisas no Seu amor. Por isso, a ênfase precisa (sempre) recair no Amor, visando não só a formação de uma ordo amoris, mas de uma theologia amoris: cordial. ${ }^{59}$ Amor que transfigura quem ama e quem é amado. ${ }^{60}$

em Cristo a plenitude de vida destinada à todos e todas "já" aconteceu antecipadamente (prolepse). Cf. PANNENBERG, W. Cristologia: lineamenti fondamentali. Brescia: Morcelliana, 1974, pp. 548-551. Cf. ainda: GONZÁLES FAUS, J. I. La humanidad nueva: ensayo de cristologia. $6^{\text {a }}$ ed. Santander: Sal Terrae, 1984, pp. 137-166/283-313; MOLTMANN, J. Teologia da esperança. $3^{\mathrm{a}}$ ed. São Paulo: Teológica; Loyola, 2005, pp. 181-288; QUEIRUGA, A. T. Repensar a ressurreição: a diferença cristã na continuidade das religiões e da cultura. São Paulo: Paulinas, 2004, pp. 21-38/77-102; SOBRINO, J. Cristologia a partir da América Latina. Petrópolis: Vozes, 1983, pp. 245-281.

${ }^{52}$ Cf. ALVES, R. Variações sobre o prazer. Santo Agostinho, Nietzsche, Marx e Babette. São Paulo: Planeta, 2011, pp. 11-12.

${ }^{53}$ Cf. Id., idem, pp. 13-14.

${ }^{54}$ Cf. DE JESUS, A. M. G.; DE OLIVEIRA, J. L. M. Teologia do prazer. São Paulo: Paulus, 2014.

${ }^{55}$ Como diz a narrativa genesíaca: "E Deus viu tudo quanto fizera, e era muito bom". Gn 1, 31. Grifo nosso.

${ }^{56}$ Cf. CAMPBELL, J. O poder do mito. São Paulo: Palas Athena, 1990.

${ }^{57}$ Pois a protologia já é escatologia. Cf. SCHWANTES, M. Projetos de esperança: meditações em Gn 1-11. São Paulo: Paulinas, 2001. Cf. também. RAHNER, K. Curso fundamental da fé. Op. cit., pp. 315-336.

${ }^{58}$ O Paraíso é promessa. Cf. MOLTMANN, J. Teologia da esperança. Op. cit., pp. 129-180.

${ }^{59}$ Um intelectus amoris: Cf. MOLTMANN, J. Experiências de reflexão teológica. Op. cit., pp. 58-61. Cf. também. SOBRINO, J. "Como fazer teologia: proposta metodológica a partir da realidade salvadorenha e latino-americana”. Perspectiva Teológica 21 (1989), pp. 285-303. ${ }^{60}$ Cf. ALVES, R. Variações sobre a vida e a morte ou O Feitiço erótico-herético da teologia. $2^{\mathrm{a}}$ ed. São Paulo: Loyola, 2009, p. 138. 
E há algo mais belo que o Amor de Deus, que o Deus-Amor? ${ }^{61}$ Eis a dimensão poi(ética) do amor.

\section{Conclusão}

Na perspectiva cristã: sem amor, sem um coração aberto a dor alheia, não há como estabelecer relações justas. E sem justiça (tsedaqah) a paz (shalom) simplesmente não é possível. Mas, se nos comprometermos com o estabelecimento de uma ordo amoris, a partir do exercício diuturno do amor, feito de pequenos gestos, então a paz poderá nascer, promovida desde o cotidiano mais prosaico. Assim, podemos transformar a vida numa caminhada que visa à reconciliação, feita do encontro entre os diferentes, que torna habitável nossa Casa comum: onde a fome de pão e de beleza $a^{62}$, de amor e de paz, seja saciada, já, aqui e agora.

\section{Referências bibliográficas}

AGOSTINHO, S. Confissões. São Paulo: Paulus, 2006.

ALVES, R. Por uma teologia da libertação. São Paulo: Fonte Editorial, 2012.

ALVES, R. Retratos de Amor. $7^{\mathrm{a}}$ ed. Campinas: Papirus, 2002.

ALVES, R. Variações sobre a vida e a morte ou O Feitiço erótico-herético da teologia. $2^{\mathrm{a}}$ ed. São Paulo: Loyola, 2009.

ALVES, R. Variações sobre o prazer. Santo Agostinho, Nietzsche, Marx e Babette. São Paulo: Planeta, 2011.

BARTH, K. Introdução à teologia evangélica. $9^{\mathrm{a}}$ ed. São Leopoldo: Sinodal, 2007.

BATAILLE, G. O erotismo. Porto Alegre: L\&PM, 1987.

BETO, F. Fome de pão e de beleza. São Paulo: Siciliano, 1991.

BINGEMER, M. C. L. Um rosto para Deus? São Paulo: Paulus, 2005.

BINGEMER, M. C. L.; FELLER, V. G. Deus-Amor: a graça que habita em nós. São Paulo: Paulinas; Valência: Siquem, 2003.

\footnotetext{
${ }^{61}$ Cf. ALVES, R. Por uma teologia da libertação. São Paulo: Fonte Editorial, 2012, pp. 9-56.

${ }^{62}$ Cf. BETO, F. Fome de pão e de beleza. São Paulo: Siciliano, 1991.
} 
BINGEMER, M. C. L.; FELLER, V. G. Deus Trindade: a vida no coração do mundo. São Paulo: Paulinas; Valência: Siquem, 2003.

BOFF, C. Teoria de método teológico. $5^{\mathrm{a}}$ ed. Petrópolis: Vozes, 2004.

BOFF, L. A Santíssima Trindade é a melhor comunidade. $11^{\mathrm{a}}$ ed. Petrópolis: Vozes, 2009.

BOFF, L. Ética e ecoespiritualidade. Petrópolis: Vozes, 2011.

BOFF, L. Experimentar Deus: a transparência de todas as coisas. Petrópolis: Vozes, 2011.

BOFF, L. "Masculino e Feminino, o que é? Fragmentos de uma ontologia". Revista de Cultura Vozes 9 (1974), pp. 677-690.

BOFF, L. O cuidado necessário. Petrópolis: Vozes, 2012.

BOFF, L. Saber cuidar: ética do humano, compaixão pela terra. $18^{\mathrm{a}}$ ed. Petrópolis: Vozes, 2012.

BOFF, L. Tempo de transcendência: o ser humano como um projeto infinito. Rio de Janeiro: Sextante, 2000.

BONHOEFFER, D. Ética. $7^{\mathrm{a}}$ ed. São Leopoldo: Sinodal, 2005.

CAMPBELL, J. O poder do mito. São Paulo: Palas Athena, 1990.

CONDEIXA, R. Do divórcio ao romance: uma nova relação entre teologia e espiritualidade. São Paulo: Editora Reflexão, 2011.

DE JESUS, A. M. G.; DE OLIVEIRA, J. L. M. Teologia do prazer. São Paulo: Paulus, 2014.

DJAVAN. "Seduzir". Faixa 2. In: Seduzir. EMI/Odeon, 1981.

FORTE, B. Teologia em diálogo: para quem quer e para quem não quer saber nada disso. São Paulo: Loyola, 2002.

FRANÇA MIRANDA, M. de. A salvação de Jesus Cristo: a doutrina da graça. São Paulo, Loyola, 2003.

FREUD, S. $O$ mal-estar na civilização. São Paulo: Penguin Classics; Companhia das Letras, 2011.

GONZÁLES FAUS, J. I. La humanidad nueva: ensayo de cristologia. $6^{\mathrm{a}}$ ed. Santander: Sal Terrae, 1984.

GUELMAN, L. C. Univvverrsso Gentileza. Curitiba: Mundo das Idéias, 2015. GUTIÉRREZ, G. Beber no próprio poço: itinerário de um povo. São Paulo: Loyola, 2000. 
GUTIÉRREZ, G. O Deus da vida. São Paulo. Loyola, 1992.

LÉVINAS, E. Entre nós: ensaios sobre a alteridade. Petrópolis: Vozes, 2005. LÉVINAS, E. Totalidade e Infinito. Lisboa: Edições 70, 2008.

LIBÂNIO, J. B. Eu creio, nós cremos: tratado da fé. São Paulo: Loyola, 2000.

MAFFESOLI, M. Homo eroticus: convivências emocionais. Rio de Janeiro: Forense Universitária, 2014.

MAIAKÓVSKI, V. Antologia poética. 4ª ed. São Paulo: Max Limonad, 1987.

MOLTMANN, J. Experiências de reflexão teológica: caminhos e formas da teologia cristã. São Leopoldo: Editora UNISINOS, 2004.

MOLTMANN, J. O Espírito da Vida: uma pneumatologia integral. Petrópolis: Vozes, 1999.

MOLTMANN, J. Teologia da esperança. $3^{\mathrm{a}}$ ed. São Paulo: Teológica; Loyola, 2005.

MOLTMANN, J. Trindade e Reino de Deus: uma contribuição para a teologia. Petrópolis: Vozes, 2000.

MORIN, E. Amor, poesia, sabedoria. $7^{\text {a }}$ ed. Rio de Janeiro: Bertrand Brasil, 2007.

MORIN, E. O Método 5: a humanidade da humanidade. $5^{\mathrm{a}}$ ed. Porto Alegre: Sulina, 2012.

PANNENBERG, W. Cristologia: lineamenti fondamentali. Brescia: Morcelliana, 1974.

PASCAL, B. Pensamentos. 2a ed. São Paulo: Martins Fontes, 2005.

PAZ, O. A dupla chama: amor e erotismo. $2^{\text {a }}$ ed. São Paulo: Siciliano, 1995.

PLATÃO. O Banquete ou do Amor. Rio de Janeiro: DIFEL, 2002.

QUEIRUGA, A. T. Repensar a ressurreição: a diferença cristã na continuidade das religiões e da cultura. São Paulo: Paulinas, 2004.

RAHNER, K. Curso fundamental da fé. $3^{\mathrm{a}}$ ed. São Paulo: Paulus, 2004.

RAHNER, K. O cristão do futuro. São Paulo: Novo Século, 2004.

ROSA, J. G. Grande Sertão: veredas. Rio de Janeiro: Nova Aguilar, 1994.

ROUSSEAU, J. J. Do contrato social. (Col. Saraiva de Bolso). São Paulo: Saraiva; Nova Fronteira, 2011. 
RUBIO, A. G. O encontro com Jesus Cristo vivo: ensaio de cristologia para os nossos dias. $15^{\mathrm{a}}$ ed. São Paulo: Paulinas, 2012.

SCHELER, M. "Ordo amoris". Tradutor: Artur Mourão. In: "LusoSofia”. Biblioteca on-line de Filosofia e Cultura, p. 14. Disponível em: $<$ http:// www.lusosofia.net/textos/20120726-scheler_ordo_amoris.pdf $>$. Acessado em 8 de julho de 2015.

SCHILLEBEECKX, E. História humana: revelação de Deus. $2^{\mathrm{a}}$ ed. São Paulo: Paulus, 2003.

SCHWANTES, M. Projetos de esperança: meditações em Gn 1-11. São Paulo: Paulinas, 2001.

SOBRINO, J. A fé em Jesus Cristo: ensaio a partir das vítimas. Petrópolis: Vozes, 2000.

SOBRINO, J. "Como fazer teologia: proposta metodológica a partir da realidade salvadorenha e latino-americana". Perspectiva Teológica 21 (1989), pp. 285-303.

SOBRINO, J. Cristologia a partir da América Latina. Petrópolis: Vozes, 1983.

SOBRINO, J. Espiritualidade da libertação. São Paulo: Loyola, 1992.

SUSIN. L. C. "Gloria Maior Deus Humilis. Prática da Teologia em novos paradigmas: um exercício". In: VV. AA. Teologia aberta ao futuro. São Paulo: SOTER; Loyola, 1997.

VATTIMO, G.; RORTY, R. “O futuro da religião”. Solidariedade, caridade e ironia. Rio de Janeiro: Relume Dumará, 2006.

Rodrigo Cardoso Condeixa da Costa

Doutor em Teologia pela Pontifícia Universidade Católica do Rio de Janeiro Rio de Janeiro / RJ - Brasil E-mail: rodrigocondeixa@ig.com.br

Recebido em: 02/09/15

Aprovado em: 07/04/16 